\title{
Kamu Harcamaları ve Ekonomik Büyüme Arasındaki İlişki: Kırgızistan Örneği
}

\author{
Raziye ABDIYEVA*, Hakan ÇETINTAŞ ${ }^{* *}$
}

ÖZ

Wagner kanununa göre ekonomik büyüme ile kamu harcamaları arasında tek yönlü bir ilişki bulunmaktadır. Milli gelirin artması kamu harcamalarının daha büyük bir oranda artmasına neden olacaktır. Diğer bir ifadeyle, ülkede ortaya çıkan sosyal ve ekonomik gelişme birlikte kişilerin kamusal mallara olan talebi de artmakta, bu da kamu harcamalarının milli gelirin artış hızından daha da yüksek oranda artması ile sonuçlanmaktadır.

Bu çalışmada Kırgızistan'da ekonomik büyüme ile kamu harcamaları arasındaki uzun dönemli ilişki ve nedensellik incelenmiştir. ARDL ve Hata Düzeltme modelleri yardımıyla Kırgızistan ekonomisinde Wagner kanununun geçerliliği test edilmiştir. Çalışmada 1995-2014 dönemini kapsayan yıllık veriler kullanılmıştır. Ampirik bulgular Kırgızistan'da ekonomik büyüme ile kamu harcamaları arasında uzun dönemde tek yönlü bir nedensellik ilişkinin bulunduğunu ve Wagner kanununun Kırgız ekonomisi için geçerli olduğunu göstermektedir.

Anahtar Kelimeler: Ekonomik Büyüme, Kamu Harcamaları, Wagner Kanunu

JEL Sınıflandırması: E62, H50

\section{Cointegration and Causality between Public Expenditure and Economic Growth: Case of Kyrgyzstan}

\begin{abstract}
According to Wagner's law there is unidirectional relationship from economic growth to public expenditure. Wagner's states that increase of national income leads to faster growth of public expenditure. In other words, out of economic and social development in the country, people will demand more public goods and it will increase public expenditure at a faster rate than national income.

This study is analyzing the long term and causality relationship between public expenditure and economic growth in Kyrgyzstan and tests the validity of Wagner's law in Kyrgyz economy by using an ARDL and Error Correction models over the period 1995 to 2014. Empirical results showed that there is an unidirectional causality relationship between economic growth and public expenditure in long term. Empirical evidence is support the validity of Wagner's law in Kyrgyz economy.
\end{abstract}

Keywords: Economic Growth, Public Expenditure, Wagner's Law

JEL Classification: E62, H50

Geliş Tarihi/Received: 14.09.2016 Kabul Tarihi/Accepted: 18.10.2016

\footnotetext{
${ }^{*}$ Yrd.Doç.Dr., Kırgısiztan-Türkiye Manas Üniversitesi, İIBBF, İktisat Bölümü, r_aziya@ yahoo.com

** Prof.Dr., Kırgısiztan-Türkiye Manas Üniversitesi, İ̈BF, İktisat Bölümü, Balıkesir Üniversitesi İİF İktisat Bölümü, cetintash@yahoo.com
} 


\section{GİRIŞ}

Kamu harcamalarının sürekli artması 19.yüzyılda iktisatçıların ilgisini çekmeye başlamıştır. A. Wagner 1800'lerin sonunda Almanya, İsviçre ve ABD gibi sanayileşmekte olan ülkelerde uzun dönemde kamu harcamalarının sürekli arttığını ve bu artışın milli gelir ile ilişkili olduğunu tespit eden ilk kişidir. Wagner'e göre kamu harcamalarının artmasının temel nedeni ülkedeki ekonomik ve sosyal gelişmedir. Kişilerin gelirlerindeki artış daha fazla ve daha kaliteli kamu hizmetlerine olan taleplerini artırarak, devlet faaliyetlerinin artmasına neden olmaktadır. Sonuçta, milli gelirin artmasına bağlı olarak kamu harcamaları da artmaktadır. Wagner kanunu olarak isimlendirilen bu kanuna göre, milli gelirdeki yüzde 1'lik artış kamu harcamalarında yüzde birden daha fazla bir artışa neden olmaktadır.

1930'lu yıllarda ortaya çıkan Keyneysen teori sonrası Wagner kanunu tartışılır bir teoriye dönüşmüştür. Her iki teori kamu harcamaları ve ekonomik büyüme arasındaki ilişkiye farklı açılardan yaklaşmaktadır (Permana and Vika, 2014:130). Wagner kanununda kamu harcamaları içsel bir değişken iken, Keynesyen teoride kamu harcamaları dışsal bir değişkendir. Diğer bir ifadeyle ilkinde kamu harcamalarının ekonomik büyüme üzerinde bir etkisi bulunmazken, ikincisinde kamu harcamaları ekonomik büyüme üzerinde pozitif bir etkiye sahiptir ve önemli bir politika aracıdır.

Wagner'in orijinal çalışmasının Cooke tarafından yapılan ilk çevirisinden sonra birçok ekonomistin Wagner kanununa olan ilgisi artmaya başlamış, 1970'lerin sonlarına doğru yeniden azalmıştır. Bununla birlikte birçok ülkede kamu harcamalarının artması, yeni ekonometrik tekniklerin bulunması ve Wagner'in çalışmasının Beihl tarafından yapılan son çevirisinden sonra kanun, tekrar ekonomistlerin ve politika yapıcılarının ilgisini çekmeye başlamışıtır (Richter ve Dimitrios, 2012:2).

Kırgızistan 1991 yılında bağımsızlığını kazanmış ve yeni piyasa ekonomisine geçmiş bir ülkedir. Geçiş döneminin başında piyasa ekonomisine uyum sağlamak için yapısal ve sosyal reformları gerçekleştirmek üzere kamu harcamaları artmıştır. Sonraki dönemlerde de altyap1 harcamaları, sosyal trensferler ve eğitim harcamalarından dolayı kamu harcamaları sürekli artış eğilimi göstermiştir. Bu çalışmada 1995-2014 dönemi arasında Kırgızistan'da kamu harcamaları ve ekonomik büyüme arasındaki ilişki ARDL ve Hata Düzeltme modelleri yardımıyla araştırılmış ve Wagner kanununun geçerliliği test edilmiştir.

\section{WAGNER KANUNU}

Wagner'e göre esas olarak sanayileşme süreci ile birlikte bir ülkede kişi başına gelir arttıkça toplam harcamalar içerisinde kamu harcamalarının payı da artmaktadır. Wagner'in 150 yıl önce yaptığı bu gözlem, gözlem öncesi yaygın olan "bir ülke zenginleştikçe kamu faaliyetlerinin de azalma eğilimi göstereceği”" biçimindeki kanı (ki bu kanı modern ekonomik düşüncede hala yaygındır) dikkate alındığında özellikle önemlidir (Peters,1996:3). Aslında Wagner Kanunu kamu harcamalarındaki artışı açıklamaya çalışan tek teşebbüs değildir. Sonrasında hem ekonomistler hem de ekonomik tarihçiler trafından kamu sektöründeki bu büyümeyi açıklayan bazı girişimler olmuştur. Örneğin Alan T. Peacock ve Jack Wiseman sosyal krizlerin kamu harcamalarında bir artışa neden olduğunu iddia ederken, Walt W. Rostow kamu harcamalarındaki artışı tamamen ekonomik büyüme paterni ve toplumların gelişimi ile ilişkilendirmektedir. William J. Baumol kamu harcamalarındaki artışın nedenini kamu sektörünün özel sektörden daha az verimli olmasına, Morris Beck ise kamu sektöründeki birim maliyetlerin özel sektördekinden daha hızlı artmasına (nispi fiyat etkisi) bağlamaktadır. Ancak Wagner kanunu, kamu harcamalarındaki artışı açıklayan ilk girişimler arasında olması açısından önemlidir (Antonis vd, 2013:458). Wagner kanunu aslında bir kamu karcamaları büyüme teorisi değildir, o kamu harcamalarının yüzyıllardır süregelen trendine ilişkin bir genellemedir (Peters, 1996:4).

Wagner kanununa göre sanayileşmekte olan ülkede kamu sektörünün büyümesinin üç temel nedeni bulunmaktadır. Bunlardan ilki, kamu faaliyetlerinin özel faaliyetleri ikamesi nedeniyle devletin idari ve koruma fonksiyonlarının artmasıdır. Sanayileşme ile birlikte, bir taraftan kamunun düzenleyici ve koruyucu faaliyetlerindeki rolünün artması, diğer taraftan kentleşme ve nüfus yoğunluğu kamu harcamalarının artmasına neden olmuştur. İkinci temel neden zaman içerisinde 
sosyal ve kültürel mal ve hizmetleri arttırma ihtiyacının ortaya çıkmasıdır. Gelir artışı toplumun daha fazla eğitim, eğlence, daha eşit bir gelir ve servet dağılımı ve daha fazla kamu hizmeti taleplerinin artmasına neden olmuştur. Ayrıca, Wagner eğitim ve kültürden bahsederken bu alanları, kollektif üreticilerin özel üreticilerden daha etkin olduğu alanlar olarak ifade etmektedir. Üçüncüsü doğal monopollerin yönetimi ve finansmanıdır. Bir taraftan teknolojide yaşanan değişimler, diğer taraftan bazı alanlarda gerekli olan yatırım miktarlarının büyüklüğü ekonomik etkinliğe ulaşmak için doğal monopollerin, etkinlik amacıyla düzenlenmesini ya da onların idaresini tamamen devletin yüklenmesini zorunlu kılmıştır. Benzer şekilde bazı ekonomik faaliyetler öyle büyük sermayeler gerektirmiştir ki (Wagner demiryolu örneğini göstermektedir.) bu projeler ancak devletin katılımı sayesinde finanse edilebilmiştir (Henrekson, 1993; Peters,1996; Sideris, 2007; Kuckuck, 2012; Permana and Vika, 2014).

Bununla birlikte bu kanunun geçerliliği 19 yy.da sanayi devriminin başlangıcında anlaşılan bir durum olabilir (Kuckuck, 2012:3). Ayrıca Wagner yaşadığı dönemde etrafinı kuşatmış olan tarihsel olaylardan da etkilenmiş olabilir. Kanun 19 yy. Almanyasında Osmanlı imparatorluğunun gerilediği ve Almanya imparatorluğunun genişlediği, ayrıca Almanya'da hızlı teknolojik gelişmenin sonucu olarak gelirin artttığı bir dönemde formüle edilmiştir (Peters, 1996:6). Bununla birlikte Wagner ekonomik ve kültürel bir ilerleme olduğu sürece kanunun geçerli olacağını kabul eder. Wagner'e göre ekonominin gelişme aşamasına bağlı olarak devletin rolü de değişir. Gelişmiş sosyal bir devletin kamu harcamaları, henüz yeni zenginleşmekte olan bir devletdeki gibi gelirdeki değişmelere aynı şekilde tepki vermez. Wagner kanununa göre bu, artan kamu faaliyetleri ile ekonomik büyüme arasındaki doğrudan bağlantının, gelişmenin sonraki aşamalarına nispeten başlangıç aşamasında geçerliliğinin daha yüksek olabileceğini göstermektedir (Mahdavi, 2009; Kuckuck, 2012).

Kanunun modern versiyonu kanunu açılamak için bireysel fayda maksimizasyonu kavramından yararlanır. Niskanen kamu harcamalarının, nüfuzlarını genişletmeye çalışan bürokratların fayda maksimizasyon davranışlarının bir sonucu olarak, kamu harcamalarının büyüme ile orantısız bir şekilde artabileceğini ifade ederken, Meltzer ve Richard ve Tabellini kamu tercihi motivasyonlarını dikkate alır. Onlar kamu harcamalarının yeniden dağıtım özelliğinin olduğunu kabul ederek kamu sektöründeki büyümeyi, daha fazla yeniden dağıtım harcaması baskısı yapan düşük gelirli seçmen sayısının artması nedeniyle, 19. ve 20. yy'da tanınan ayrıcalıkların yayılmasının bir sonucu olarak açıklar. Tridimas ise çıkar gruplarının çoğunluk kuralından faydalanarak devleti kuşatma rolü üzerine vurgu yapmaktadır (Sideris, 2007:5).

Wagner kanununun Bird tarafindan açıklanmaya çalışan modern versiyonunda kanun şu şekilde çalışmaktadır: sanayileşen ülkelerde kişi başına gelir arttıkça kamu sektörü genişlemekte ve kamu harcamaları artmaktadır (Richter and Dimitrios, 2012:2).

Aslında, kanunun gerek geleneksel gerekse modern versiyonunda kamu harcamalarındaki artışın, ekonomik büyümenin doğal bir sonucu olduğu kabul edilmektedir (Verma ve Arora, 2010). Sanayileşme, sosyal gelişme ve kişilerin reel gelirleri daha fazla ve kaliteli kamu hizmetlerine olan talebin artmasına, sonuçta devlet faaliyetlerinin genişlemesine neden olmaktadır.

\section{AMPÍRIK LITERATÜR}

Wagner kanununun geçerliliği üzerine literatürde çok sayıda çalışma bulunmaktadır. Burada bu çalışmalardan bazılarına yer verilmiştir. Abizadeh ve Gray (1985) 55 ülke için Wagner hipotezinin geçerliliğini araştırmış, hipotezin zengin ülkeler için geçerli olduğunu, fakat gelir seviyesi çok düşük ülkeler için geçerli olmadığını bulmuşlardır. Thornton (1999) 'un19.yüzyılın ortasından 1913 yılı arasında altı Avrupa ülkesi için yapmış olduğu çalışma ve Ram (1986)'ın 63 ülke için yaptığı çalışmanın sonuçları Wagner hipotezinin sözkonusu ülkeler için geçerli olduğunu göstermektedir.

Yamak ve Küçükkale (1997) Türkiye'de 1950-1994 döneminde Wagner hipotezinin geçerliliğini araştırmışlar ve kanunun incelenen dönemde geçerli olduğu sonucuna ulaşmışlardır. Bağdigen ve Çetintaş ise (2004) Türkiye'de kamu harcamaları ile ekonomik büyüme arasında ilişkiyi 1965-2000 
dönemi için Granger Nedensellik testi ile eşbütünleşme testini kullanarak tahmin etmiş ve GSYİH ile kamu harcamaları arasında herhangi bir ilişki bulamamışlardır.

Zheng v.d. (2010) Wagner hipotezinin geçerliliğini Çin için test etmişlerdir. Araştırma 19522007 dönemini kapsamaktadır ve Granger nedensellik testi ve STV (smooth time varying) modeli kullanılmıştır. Yapılan araştırma sonucunda ilgili dönemde Çin için Wagner hipotezinin geçerliliğini destekleyen güçlü bir bağlantı bulunamamıştır.

Verma ve Arora (2010) Hindistan ekonomisinde sözkonusu hipotezin çalışıp çalışmadığını test etmişlerdir. Çalı̧̧ma 1950/51 ve 2007/2008 dönemi için yapılmış ve eşbütünleşme testi, hata düzeltme modeli kullanılmıştır. Ilımlı liberalizasyon dönemi olan ilk dönem için hipotezin geçerli olmadığı tahmin edilmiş iken sıkı liberalizasyon olarak isimlendirilen ikinci dönemde Wagner hipotezinin geçerli olduğunu sonucuna ulaşmışlardır.

Jaén-García (2011) İspanya'nın 17 bölgesinin 1984-2003 dönemine ait verilerini kullanarak Wagner hipotezinin geçerliliğini panel eşbütünleşme modeli yardımıyla incelemiştir. Çalışmanın sonucuna göre Wagner hipotezinin İspanya'da geçerli olduğu, özellikle kişi başına geliri düşük olan bölgelerde, söz konusu gelirin İspanya'daki ortalama düzeye yaklaştıkça esnekliğinin daha yüksek olduğu görülmüştür. Bu bulgu bölgeler zenginleştikçe kamu sektörünün ekonomideki rolünün daha hızlı büyüdüğü biçiminde yorumlanmıştır.

Richter ve Dimitrios (2012) 1850-2010 döneminde Wagner hipotezinin geçerli olup olmadığını İngiltere için araştırmış ve milli gelir ile kamu harcamaları arasında uzun dönemli bir ilişkinin olduğunu bulmuştur.

Bojanic (2013) Bolivya'da Wagner hipotezinin geçerliliğini 1994-2010 dönemi için eşbütünleşme testi ve hata düzeltme modellerini kullanarak araştırmıştır. Wagner hipotezinin dokuz versiyonunu kullanmış ve çalışmanın sonucunda altısında kamu harcamaları ile GSYIHH arasında iki yönlü bir ilişki bulmuştur.

Oktayer ve Oktayer (2013) Türkiye'de 1950-2010 dönemi için Wagner hipotezinin geçerliliğini ARDL yöntemini kullanarak araştırmışlardır. Bu çalışmada yazarlar ilk olarak kamu harcamaları ile ekonomik büyüme arasındaki birebir ilişkiyi analiz etmiş, daha sonra ilişkiyi modele enflasyon değiş̧kenini ekleyerek tahmin etmişlerdir. İki değişkenli modelde kamu harcamaları ile ekonomik büyüme arasında uzun dönemli bir ilişki bulunmaz iken, üç değişkenli modelde uzun dönemli bir ilişki olduğunu sonucuna ulaşmışlardır.

Bayrak ve Esen (2014) 1995-2012 yılları arasında 27 OECD ülkesi için Wagner hipotezinin geçerliliğini araştırmıştır. Eşbütünleşme ve hata düzeltme yöntemlerini kullanarak yaptıkları çalışmada, OECD ülkelerinde ekonomik büyüme ile kamu harcamaları arasında uzun dönemli bir ilişkinin bulunduğu ve kamu harcamalarının uzun dönem gelir esnekliğinin bu ülkelerde 0,26 ile 1,26 arasında değiştiğini bulmuşlardır..

Yine Bayrak ve Esen (2015) Azerbaycan, Kazakistan, Kırgizistan, Özbekistan ve Türkmenistan'da 1990-2012 dönemi için kamu harcamalarının ekonomik büyüme üzerindeki etkilerini, panel eş-bütünleşme ve nedensellik testleri kullanarak araştırmışlardır. Bulunan sonuçlar, bu ülkelerde kamu harcamaları ile ekonomik büyüme arasında uzun dönemde pozitif ve istatistiksel olarak anlamlı ilişkinin olduğunu göstermektedir. Ayrıca, uzun dönemde kamu harcamalarında meydana gelen \%1'lik bir artış, ekonomik büyümeyi yaklaşı \% 0.85 oranında arttırmaktadır.

Aslında Wagner, kanunun geçerliliğini araştırmak için bir formülasyon sunmadığ gibi, kanun üzerine yapılan bazı yorumlarda da, büyüklüğün nasıl ölçüleceğine ya da diğer bir ifadeyle kamunun milli gelirdeki payı mı, yoksa kamunun mutlak büyüklüğü ile mi ölçüleceğine yönelik bir açıklığın olmadığı ileri sürülmektedir. Bununla birlikte kanunun kişi başına gelir arttıkça kamu sektörünün milli gelirdeki nispi payının artan bir tahmincisi olarak yorumlanabileceğine ilişkin literatürde yaygın bir konsensusun olduğu görülmektedir (Henrekson, 1993:407-408). Son 50 y1l boyunca bu ilişkinin araştırılmasında literatürde yaygın olarak kullanılan 6 farklı versiyonu bulunmaktadır. Ayrıca Bird Wagner kanunun geçerliliğini araştırmak için yatay kesit çalışmaların uygun olmadığını ifade etmiştir. 
Kamu sektöründeki temel değişikliklerin tek bir ülkede ve uzun bir zaman dilimi içerisinde ortaya çıan bir süreç olduğunu belirtmiştir (Henrekson,1993; Verma and Arora, 2010; Richter ve Dimitrios, 2012).

Tablo 1: Wagner Hipotezinin Test Edilmesinde Kullanılan Versiyonlar

\begin{tabular}{|c|c|c|c|}
\hline \multirow[b]{2}{*}{ Model 1} & \multicolumn{3}{|l|}{ Model } \\
\hline & $\mathrm{LGt}=\beta_{0}+\beta_{1} \mathrm{LGDPt}+\mu \mathrm{t}$ & $\beta_{1}>0$ & $\begin{array}{l}\text { Peacock-Wisemann'in geleneksel } \\
\text { versiyonu }\end{array}$ \\
\hline Model 2 & $\mathrm{LGt}=\gamma_{0}+\gamma_{1} \mathrm{~L}(\mathrm{GDP} / \mathrm{P})_{\mathrm{t}}+\mu \mathrm{t}$ & $\gamma_{1}>1$ & Goffman'1n versiyonu \\
\hline Model 3 & $\begin{array}{l}\mathrm{LR}(\mathrm{G} / \mathrm{GDP})_{\mathrm{t}}=\theta_{0}+\theta_{1} \mathrm{LGDPt}+ \\
\mu \mathrm{t}\end{array}$ & $\theta_{1}>0$ & $\begin{array}{l}\text { Mann'ın versiyonu (Peacock- } \\
\text { Wisemann'ın pay versiyonu) }\end{array}$ \\
\hline Model 4 & $\begin{array}{l}\mathrm{LR}(\mathrm{G} / \mathrm{GDP}) \mathrm{t}=\alpha_{0}+\alpha_{1} \\
\mathrm{~L}(\mathrm{GDP} / \mathrm{P}) \mathrm{t}+\mu \mathrm{t}\end{array}$ & $\alpha_{1}>0$ & Musgrave'nin versiyonu \\
\hline Model 5 & $\mathrm{~L}(\mathrm{G} / \mathrm{N}) \mathrm{t}=\lambda_{0}+\lambda_{1} \mathrm{~L}(\mathrm{GDP} / \mathrm{P}) \mathrm{t}+\mu \mathrm{t}$ & $\lambda_{1}>1$ & Gupta/Michas versiyonu \\
\hline Model 6 & $\mathrm{LGCt}=\psi_{0}+\psi_{1} \mathrm{LGDPt}+\mu \mathrm{t}$ & $\psi_{1}>1$ & Pryor'un versiyonu \\
\hline \multicolumn{4}{|c|}{$\begin{array}{l}\text { Not: L-Logaritması, , P-Nüfusu, G- kamu harcamalarını, GDP-GSYï, GC - Yatırım hariç Devlet Tüketimini, } \beta 0 \text {, } \\
\theta_{0}, \alpha_{0}, \lambda_{0} \psi_{0} \text { sabit katsayısını, } \beta_{1}, \gamma_{1}, \theta_{1}, \alpha_{1}, \lambda_{1} \psi_{1} \text { - gelir esnekliğini, } \mu_{t} \text { - hata terimini göstermektedir. }\end{array}$} \\
\hline
\end{tabular}

\section{KIRGIZISTAN'DA KAMU HARCAMALARININ GELIŞIMI}

Kırgızistan 1991 yılında eski SSCB'nin dağılması ile bağımsızlığına kavuşmuştur. İlk bağımsızlık yıllarında eski Sovyetler Birliği ülkeleri ile olan ekonomik bağlarının kopması ve Sovyetler Birliğinden bütçeye aktarılan transferlerin durdurulması ile ciddi şoklar yaşanmıştır. GSYIHH 1991-1995 arasında \% 50 oranında bir azalma göstermiş, ancak 1995'lerden itibaren istikrarlı bir artış göstermeye başlamıştır.

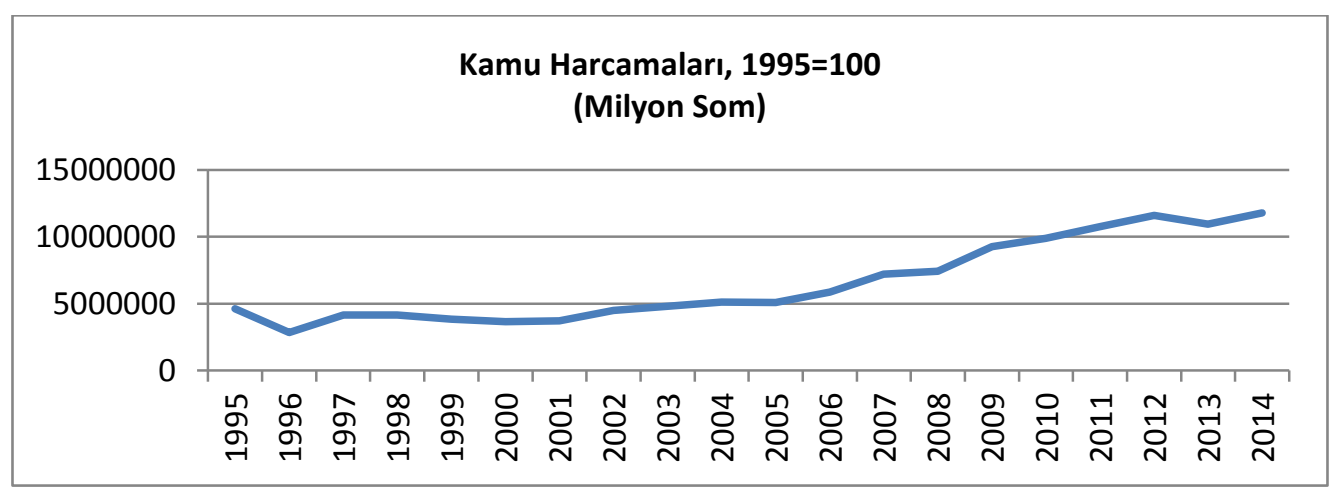

Şekil 1. Reel Kamu Harcamaları, 1995-2014 y1llar.

Kaynak: Kırgız Cumhuriyeti İstatistik Komitesi, www.stat.kg 
Şekil 1 Kırgızistan'da reel kamu harcamalarının yıllar itibariyle gelişimini göstermektedir. Şekilden de görüleceği gibi kamu harcamaları 1997 ile 2005 yılları arasında çok fazla bir değişme göstermemiştir. 2005 yılından sonra sürekli bir artış eğilimine girmiştir. Bu tarihten sonra kamu harcamalarındaki artışın en önemli nedenlerinden biri, 2005 yılında ülkede yaşanan devrim ve sonrasındaki hükümet değişikliğidir. Bu değişiklikle birlikte hükümet politikalarındaki değişim, özellikle sosyal harcamaların artmasına dolayısıyla kamu harcamalarının artışına neden olmuştur.

Şekil 2 ise kamu harcamalarının GSYİH'ya oranını göstermektedir. Şekilden de gürüleceği gibi 1995 ve 2001 yılları arasında kamu harcamalarının GSYİH'daki payının sürekli düştüğü, 20022012 arasında ise genel olarak yükselme eğilimi gösterdiği izlenmektedir.

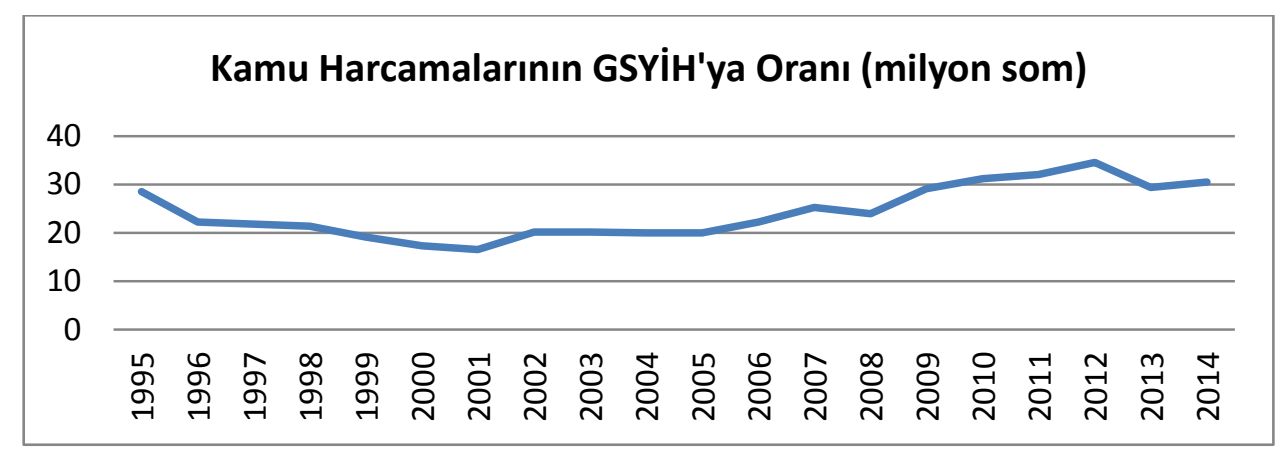

Şekil 2: Kamu Harcamalarının GSYIH'ya Oranı

Kaynak: Kırgız Cumhuriyeti İstatistik Komitesi, www.stat.kg

Kırgızistan'da Kırgız Cumhuriyeti Milli İstatistik Komitesi’nin verilerine göre 2015 yılında kamu harcamalarının \%25'i eğitim harcamaları, \% 24'ü sosyal koruma ve \% 12'si sağlık harcamalarından oluşmaktadır. Ülkede eğitim hizmetlerinin erişebilirliği yeterli seviyede iken, Uluslararası Öğrenci Değerlendirme Programı (PISA) kapsamında Kırgızistan'da yapılan sınav sonucunda, 15 yaşındaki öğrencilerin \%80'inin okuma becerisinde ikinin altında not aldıkları ve fonksiyonel olarak cahil olarak sınıflandırıldığı açıklanmıştır. 2013-2014 Küresel Rekabet Raporuna göre ise ilkokulların kalitesi açısından Kırgızistan 148 ülke arasından 113. sıradadır. Sağlık hizmetlerinin kapsamı veya erişilebilirliği yeterli derece iken halkın sağlık hizmetlerinin kalitesi ile ilgili memnuniyetsizliği yüksektir (World Bank, 2014: 30). Sosyal koruma hizmeti ise Kırgızistan'da karmaşık ve aşırı maliyetlidir. Bunun dışında halkın en fakir diliminin sadece $1 / 5$ 'i sosyal koruma sisteminden yararlanabilmektedir (IMF, 2016: 9). Böylece, Kırgızistan'da kamu hizmetlerinin sayısının arttığı fakat kalite ve etkinliğinin yükselmediği görülmektedir

\section{VERİ, YÖNTEM VE BULGULAR}

\subsection{Veri}

Çalışma 1995-2014 dönemini kapsamaktadır ve yıllık veriler kullanılmıştır. Kamu harcamaları (EXP) ve Devlet tüketimi (GC- Devlet tüketimi devletin yatırım harcamaları hariç, cari harcamaları ve transfer harcamalarından oluşmaktadır) ile ilgili veriler Kırgızistan Milli İstatistik Komitesinden kişi başına düşen GSYIH (PGDP) ve kişi başına düşen kamu harcamalarına (PEXP) ilişkin veriler Kırgızistan Milli İstatistik Komitesinden, GSYİH verisi (GDP) Kırgızistan Merkez Bankasından, GSYIH deflatörü Dünya Bankasından alınmıştır (https://www.quandl.com, 01.05.2016). Tüm seriler reel hale dönüştürülmüş ve logaritmaları alınmıştır.

\subsection{Ekonometrik Yöntem ve Bulgular}

Granger ve Newbold (1974) ekonometrik tahminlerde durağan olmayan zaman serileriyle çalışılması halinde sahte regresyon probleminin ortaya çıkabileceğini ifade etmiştir. Sahte regresyon 
probleminden kaçınmak için serilerin durağanlığının araştırılması önemlidir. Bu nedenle ilk olarak geleneksel ADF ve PP birim kök testleri kullanılarak serilerin durağanlığı araştırılmıştır.

Tablo 2 ADF ve PP birim kök test sonuçlarını göstermektedir. Her iki testte de serilerin düzey itibariyle birim kök içerdiğini söyleyen $\mathrm{H}_{0}$ hipotezi \%5 önem düzeyinde tüm seriler için reddedilememektedir. Durağan olmayan serilerin birinci farkları alınarak birim kök testi yapıldığında, $\mathrm{H}_{0}$ hipotezi $\% 1$ ve $\% 5$ önem düzeyinde reddedilmekte ve serilerin farklarının durağan olduğu sonucuna varılmaktadır.

Tablo 2. ADF ve PP Birim Kök Test Sonuçları.

\begin{tabular}{lllll}
\hline Değişkenler & $\begin{array}{l}\text { ADF Test } \\
\text { İstatistikleri }\end{array}$ & Durağanlık & $\begin{array}{c}\text { PP Test } \\
\text { Istatistikleri }\end{array}$ & Durağanlık \\
\hline Ln GDP & $-3,27(4) * *[-3.09]$ & $\mathrm{I}(1)$ & $-9,92(17) * * *[-3.09]$ & $\mathrm{I}(1) /$ \\
\hline Ln EXP & $-4,47(0) * * *[-3.04]$ & $\mathrm{I}(1)$ & $-4,46(1) * * *[-3.04]$ & $\mathrm{I}(1)$ \\
\hline Ln PGDP & $-3.91(2) * * *[-3.06]$ & $\mathrm{I}(1)$ & $-9.73(17) * * *[-3.04]$ & $\mathrm{I}(1)$ \\
\hline Ln PEXP & $-4.39(0) * * *[-3.04]$ & $\mathrm{I}(1)$ & $-4,37(1) * * *[-3.04]$ & $\mathrm{I}(1)$ \\
\hline Ln GC & $-3,90(3) * * *[-3.08]$ & $\mathrm{I}(1)$ & $-3,11(3)^{* *}[-3.04]$ & $\mathrm{I}(1)$ \\
\hline EXP/GDP & $-4,84(0) * * *[-3.04]$ & $\mathrm{I}(1)$ & $-4.56(0) * * *[-3.04]$ & $\mathrm{I}(1)$ \\
\hline
\end{tabular}

ADF ve PP testlerinde sabit içeren model kullanılmıstır. ** - \%5 ve *** - \%1 seviyesinde durağan olduğunu göstermektedir. Ayraç içindeki değerler \%5 MacKinnon kritik değerlerini, parantez içi değerler optimal gecikme uzunluklarını göstermektedir. Optimal gecikme uzunlukları Akaike Bilgi Kriterine göre belirlenmiş ve maksimum gecikme 4 olarak alınmıştır.

Ancak, yapısal değişmelerin varlığında geleneksel birim kök testleri yetersiz kalabilir ve değişkenlerin durağan olmadığına yalnızca bu test sonuçlarına dayalı olarak karar vermek yanıltıcı olabilir. Bu nedenle hem yapısal değişmeyi test etmek, hem de ADF ve PP birim kök testleri ile bulunan sonuçları kontrol etmek amacıyla Zivot ve Andrews (1992) birim kök testi kullanılmıştır. ZA birim kök testinin denklemleri aşağıdaki gibidir:

Model A:

$$
D d_{t}=m_{0}{ }^{A}+m_{1}{ }^{A} d_{t-1}+m_{2}{ }^{A} t+m_{3}{ }^{A} D U_{t}+\sum_{j=1}^{k} f_{j}{ }^{A} D d_{t-j}+e_{t}
$$

Model B:

$$
\Delta d_{t}=\mu_{0}^{B}+\mu_{1}^{B} d_{t-1}+\mu_{2}^{B} t+\mu_{3}^{B} D T_{t}+\sum_{j=1}^{k} \phi_{j}{ }^{B} \Delta d_{t-j}+\varepsilon
$$

Model C: $\quad \Delta d_{t}=\mu_{0}{ }^{C}+\mu_{1}^{C} d_{t-1}+\mu_{2}{ }^{C} t+\mu_{3}{ }^{C} D U_{t}+\mu_{4}{ }^{C} D T_{t}+\sum_{j=1}^{k} \phi_{j}{ }^{C} \Delta d_{t-j}+\varepsilon_{t}$

$t>$ TB ise $\mathrm{DU}_{\mathrm{t}}=1$ ve $\mathrm{DT}_{\mathrm{t}}^{*}=t$ aksi takdirde 0 'dır. Burada $\mathrm{t}$ tahmin dönemini, $\mathrm{DU}_{\mathrm{t}}$, ortalamada meydana gelen kırılmayı, TB olası kırılma noktasını temsil eder. Model $A$, trend durağan alternatif hipotez altında, trend fonksiyonunun sabitinde bir değişim olduğunu; Model $B$, trend fonksiyonun eğiminde bir değişim olduğunu; Model $C$ ise her iki değişimin aynı anda gerçekleştiğini kabul etmektedir. 
Tablo 3. ZA Yapısal Kırılmalı Birim Kök Test Sonuçları

\begin{tabular}{|c|c|c|c|c|c|c|}
\hline & \multicolumn{2}{|c|}{ Model A } & \multicolumn{2}{|c|}{ Model B } & \multicolumn{2}{|c|}{ Model C } \\
\hline \multicolumn{7}{|l|}{ LnGDP } \\
\hline Test istatistiği & \multicolumn{2}{|c|}{$-4,338$} & \multicolumn{2}{|c|}{-4.160} & \multicolumn{2}{|c|}{-4.251} \\
\hline Kırllma noktast & \multicolumn{2}{|c|}{2010} & \multicolumn{2}{|c|}{1998} & \multicolumn{2}{|c|}{2008} \\
\hline \multicolumn{7}{|l|}{ LnEXP } \\
\hline Test istatistiği & \multicolumn{2}{|c|}{-4.122} & \multicolumn{2}{|c|}{-3.311} & \multicolumn{2}{|c|}{-3.498} \\
\hline Kırılma noktası & \multicolumn{2}{|c|}{2007} & \multicolumn{2}{|c|}{2001} & \multicolumn{2}{|c|}{1999} \\
\hline \multicolumn{7}{|l|}{ LnPGDP } \\
\hline Test istatistiği & \multicolumn{2}{|c|}{$-4,288$} & \multicolumn{2}{|c|}{$-4,036$} & \multicolumn{2}{|c|}{$-4,850$} \\
\hline Kırılma noktası & \multicolumn{2}{|c|}{2010} & \multicolumn{2}{|c|}{2010} & \multicolumn{2}{|c|}{2008} \\
\hline \multicolumn{7}{|l|}{ LnPEXP } \\
\hline Test istatistiği & \multicolumn{2}{|c|}{$-4,147$} & \multicolumn{2}{|c|}{$-3,139$} & \multicolumn{2}{|c|}{$-3,364$} \\
\hline Kırılma noktası & \multicolumn{2}{|c|}{2007} & \multicolumn{2}{|c|}{2001} & \multicolumn{2}{|c|}{1999} \\
\hline \multicolumn{7}{|l|}{ LGC } \\
\hline Test istatistiği & \multicolumn{2}{|c|}{$-4,083$} & \multicolumn{2}{|c|}{$-3,468$} & \multicolumn{2}{|c|}{$-3,850$} \\
\hline Kırılma noktast & 19 & & 20 & & & 99 \\
\hline EXP/GDP & & & & & & \\
\hline Test istatistiği & $-4,4$ & & $-3,2$ & & & 556 \\
\hline Kırılma noktast & 20 & & 20 & & & 09 \\
\hline Kritik dĕgerler & $\% 1$ & $\% 5$ & $\% 1$ & $\% 5$ & $\% 1$ & $\% 5$ \\
\hline & $-5,34$ & $-4,80$ & $-4,93$ & $-4,42$ & $-5,57$ & $-5,08$ \\
\hline
\end{tabular}

Tablo 3'te yapısal kırılmalı ZA birim kök test sonuçları görülmektedir. Farklı modellere göre kırılma yılları değişmektedir. LnGDP serisi için model A 2010, model B 1998, model C'de 2008 y1lında; LnEXP serisi için model A 2007, model B 2001, model C'de 1999 yılında; LnPGDP serisi için model A 2010, model B 2010, model C'de 2008 yılında; LnPEXP serisi için model A 2007, model B 2001, model C'de 1999 y1lında; LGC serisi için model A 1999, model B 2001, model C'de 1999 y1lında ve son olarak EXP/GDP serisi için model A 2009, model B 2001 ve model C'de 2009 yılında yapısal bir kırılmanın var olduğunu göstermektedir.

Bu kırılmaların önemli nedenlerinden biri 1998-1999 yıllarında yaşanan Asya ve Rusya krizidir. Bu krizlerin, Kırgız ekonomisi üzerindeki negatif etkileri GSYIH ve kamu harcamalarının azalmasına yol açmıştır. 2010'da da siyasi darbe ve etnik savaş sonucunda GSYİH \% 1.4 oranında düşmüştür. 2001'de ise kamu gelirlerinin artması ile birlikte kamu harcamaları da artmıştır. Kamu gelirlerinin GSYİH'daki oranı, Katma Değer Vergisi gelirlerinin artması, kamu işletmelerinden bütçeye aktarılan temettüler ve Kırgız Cumhuriyeti Merkez Bankasının daha yüksek kar transferleri sonucu 2001'de bir önceki yıla göre yaklaşık 2 puan artmıştır (IMF, 2002). Diğer taraftan, 2007-2008 yıllarında Rusya ve Kazakistan ekonomisinin hızla büyümesi, işçi göçmenlerinin ülkeye gönderdikleri transferlerin artması (transferlerin GSYİH'ya oranı 2008'de 28,6'ya ulaşmıştır), ihracat ve Çin'den Rusya'ya yeniden ihracatın yükselmesi nedeni ile ekonomik büyüme \%8'e ulaşmıştır (Sentr sotsialnoekonomiçeskih issledovaniy, 2011). Bu gelişmelerden dolayı ülkede GSYIH ve kamu harcamalarında da artış yaşanmıştır. 2009'da ise küresel finansal krizin etkisiyle GSYIH'da düşme olmuştur ve devlet 
reel sektörü desteklemek amacıyla kamu harcamalarını arttırmak zorunda kalmıştır (World Bank, 2014).

Tüm seriler için, her üç modelde de test istatistiğinin değerinin kritik değerden daha küçük olduğu tespit edilmiştir. Dolayısıyla, birim kök yokluk hipotezi \%5 önem düzeyinde reddedilememektedir. Diğer bir ifadeyle, ZA birim kök test sonuçları kırılmalar dikkate alındığında serilerin farkının durağan olduğunu göstermektedir. Bu sonuçlar daha önce ADF ve PP testi ile bulunan sonuçları doğrulamakta ve serilerin aynı düzeyde entegre olduğunu göstermektedir.

Birim kök testlerinden sonra ikinci olarak seriler arasında uzun dönemli bir ilişkinin olup olmadığı araştırılmıştır. Çalışmada Pesaran vd. (2001) tarafından geliştirilen koentegrasyon yaklaşımı kullanılmıştır. Bunun bir nedeni bu yaklaşımla değişkenlerin bütünleşme dereceleri dikkate alınmadan, onların düzey değerlerinin arasında eşbütünleşme ilişkisinin var olup olmadığını test etmenin mümkün olmasıdır. Diğer bir nedeni bu testin az sayıda gözleme sahip olan çalışmalara uygulanabilmesidir (Narayan, 2005).

Sınır testinin uygulanabilmesi için önce kısıtlanmamış hata düzeltme modeli (UECM) tahmin edilir. $\mathrm{Bu}$ nedenle değişkenler arasındaki uzun dönemli ilişkiyi tahmin etmek için aşağıdaki hata düzeltme modelleri tahmin edilmiştir.

$$
\begin{aligned}
& \Delta \ln E X P=\alpha_{0}+\sum_{i=1}^{k} \alpha_{1 i} \Delta \ln E X P_{t-i}+\sum_{i=0}^{l} \alpha_{2 i} \Delta \ln G D P_{t-i}+\alpha_{3} \ln E X P_{t-1}+ \\
& +\alpha_{4} \ln G D P_{t-1}+\varepsilon_{1} \\
& \Delta \ln E X P=\alpha_{0}+\sum_{i=1}^{k} \alpha_{1 i} \Delta \ln E X P_{t-i}+\sum_{i=0}^{l} \alpha_{2 i} \Delta \ln P G D P_{t-i}+\alpha_{3} \ln E X P_{t-1}+ \\
& +\alpha_{4} \ln P G D P_{t-1}+\varepsilon_{1} \\
& \Delta \ln E X P / G D P=\alpha_{0}+\sum_{i=1}^{k} \alpha_{1 i} \Delta \ln E X P / G D P_{t-i}+\sum_{i=0}^{l} \alpha_{2 i} \Delta \ln G D P_{t-i} \\
& +\alpha_{3} \Delta \ln E X P / G D P_{t-1}+\alpha_{4} \ln G D P_{t-1}+\varepsilon_{1} \\
& \Delta \ln E X P / G D P=\alpha_{0}+\sum_{i=1}^{k} \alpha_{1 i} \Delta \ln E X P / G D P_{t-i}+\sum_{i=0}^{l} \alpha_{2 i} \Delta \ln P G D P_{t-i} \\
& +\alpha_{3} \Delta \ln E X P / G D P_{t-1}+\alpha 4 \ln P G D P_{t-1}+\varepsilon_{1} \\
& \Delta \ln P E X P=\alpha_{0}+\sum_{i=1}^{k} \alpha_{1 i} \Delta \ln P E X P_{t-i}+\sum_{i=0}^{l} \alpha_{2 i} \Delta \ln P G D P_{t-i} \\
& +\alpha_{3} \ln P E X P_{t-1}+\alpha_{4} \ln P G D P_{t-1}+\varepsilon_{1} \\
& \Delta \ln G C=\alpha_{0}+\sum_{i=1}^{k} \alpha_{1 i} \Delta \ln G C_{t-i}+\sum_{i=0}^{l} \alpha_{2 i} \Delta \ln G D P_{t-i} \\
& +\alpha_{3} \ln G C_{t-1}+\alpha_{4} \ln G D P_{t-1}+\varepsilon_{1}
\end{aligned}
$$

Burada koentegrasyon ilişkisi ( $H_{0}: a_{3}=a_{4}=0$ ) hipotezinin test edilmesi yoluyla yapılır ve hesaplanan F istatistiği Pesaran vd. (2001)'deki tablo alt ve üst kritik değerleri ile karşılaştırılır. Eğer hesaplanan $\mathrm{F}$ istatistiği alt kritik değerinden küçükse, seriler arasında koentegrasyonun olmadığına 
karar verilir. Hesaplanan $\mathrm{F}$ istatistiği alt ve üst kritik değerler arasında ise kesin bir yorum yapılamamakta ve diğer koentegrasyon yöntemleri önerilmektedir. Hesaplanan F istatistiği üst kritik değerin üzerinde olduğu durumda ise seriler arasında bir koentegrasyon ilişkisinin bulunduğuna karar verilmektedir.

Tablo 4. Sınır Testi Sonuçları

\begin{tabular}{|c|c|c|c|c|c|c|c|}
\hline Model & & & & & & $\begin{array}{c}\begin{array}{c}\text { En uygun } \\
\text { model }\end{array} \\
\end{array}$ & F ist. \\
\hline Model 1 & \multicolumn{5}{|c|}{$\mathrm{LREXPt}=\beta 0+\beta 1 \mathrm{LRGDPt}+\mu \mathrm{t}$} & 1.0 . & 7.27 \\
\hline Model 2 & \multicolumn{5}{|c|}{$\mathrm{LREXPt}=\beta 0+\beta 1 \mathrm{LRPGDPt}+\mu \mathrm{t}$} & 1.0 . & 7.75 \\
\hline Model 3 & \multicolumn{5}{|c|}{$\begin{array}{l}\mathrm{LR}(\mathrm{EXP} / \mathrm{GDP}) \mathrm{t}=\beta 0+\beta 1 \mathrm{LRGDPt}+ \\
\mu \mathrm{t}\end{array}$} & 1.1 . & 39.93 \\
\hline Model 4 & \multicolumn{5}{|c|}{$\begin{array}{l}\mathrm{LR}(\mathrm{EXP} / \mathrm{GDP}) \mathrm{t}=\beta 0+\beta 1 \mathrm{LRPGDPt} \\
+\mu \mathrm{t}\end{array}$} & 1.1 . & 40.34 \\
\hline Model 5 & \multicolumn{5}{|c|}{$\mathrm{LRPEXPt}=\beta 0+\beta 1 \mathrm{LRPGDPt}+\mu \mathrm{t}$} & 1.0 & 7.68 \\
\hline Model 6 & \multicolumn{5}{|c|}{$\mathrm{LRGCt}=\beta 0+\beta 1 \mathrm{LRGDPt}+\mu \mathrm{t}$} & 1.0 & 4.75 \\
\hline \multicolumn{8}{|c|}{ Kritik değerler } \\
\hline \multicolumn{4}{|c|}{ Pesaran vd.(2001) } & \multicolumn{4}{|c|}{ Narayan(2005) } \\
\hline \multicolumn{2}{|c|}{$\% 5$} & \multicolumn{2}{|c|}{$\% 1$} & \multicolumn{2}{|c|}{$\% 5$} & \multicolumn{2}{|c|}{$\% 1$} \\
\hline $\mathrm{I}(0)$ & $\mathrm{I}(1)$ & $\mathrm{I}(0)$ & $\mathrm{I}(1)$ & $\mathrm{I}(0)$ & $\mathrm{I}(1)$ & $\mathrm{I}(0)$ & $\mathrm{I}(1)$ \\
\hline 4.87 & 5.85 & 6.34 & 7.52 & 4.267 & 5.473 & 6.183 & 7.873 \\
\hline
\end{tabular}

F-istatistiği için kritik değerler Pesaran vd. (2001) ve Narayan (2005)'dan alınan değerleri göstermektedir.

Tablo 4 tüm modeler için tahmin edilen koentegrasyon test sonuçları göstermektedir. Tablodan da görüldüğü gibi uzun dönem ilişkiyi test eden altı modelin ilk beşinde $\mathrm{F}$ istatistiğinin değeri Narayan (2005) ve Pesaran (2001) vd.'den alınan üst kritik değeri aşmaktadır. Daha açık bir ifadeyle, ilk beş modele göre kamu harcamaları ve ekonomik büyüme arasında uzun dönemde bir eşbütünleşme ilişskisinin bulunduğuna karar verilmektedir. 6 . modelde tahmin edilen $\mathrm{F}$ istatistiğinin değeri ise 4.75'dir ve bu değer hem Narayan (2005) 'dan hem de Pesaran vd. (2001)'den alınan alt ve üst kritik değerler arasında olduğu için bu aşamada bu modele göre değişkenler arasında koentegrasyona yönelik bir karar verilememektedir.

\section{Tablo 5. Modellerin Uzun Dönem Tahmini}

\begin{tabular}{|c|c|c|c|c|c|c|}
\hline Model & $\begin{array}{l}\text { Değişk } \\
\text { en }\end{array}$ & $\begin{array}{c}\text { Katsay } \\
1\end{array}$ & t-ist & $\overline{\chi_{\mathrm{NOR}}^{2}}$ & $\chi^{2}$ SER & $\overline{\chi_{\mathrm{LM}}^{2}}$ \\
\hline (1)LREXPt $=\beta 0+\beta 1 \mathrm{LRGDPt}+\mu \mathrm{t}$ & $\begin{array}{l}\mathrm{C} \\
\text { LnGDP }\end{array}$ & $\begin{array}{c}-12.09 \\
2.05\end{array}$ & $\begin{array}{c}-4.06 \\
6.96\end{array}$ & $\begin{array}{c}0.94 \\
(0.62)\end{array}$ & $\begin{array}{c}1.17 \\
(0.55)\end{array}$ & $\begin{array}{c}0.77 \\
(0.67)\end{array}$ \\
\hline (2)LREXPt $=\beta 0+\beta 1$ LRPGDPt $+\mu \mathrm{t}$ & $\begin{array}{l}\text { C } \\
\text { LnPGD } \\
\text { P }\end{array}$ & $\begin{array}{c}23.89 \\
2.84\end{array}$ & $\begin{array}{c}10.86 \\
6.95\end{array}$ & $\begin{array}{c}0.84 \\
(0.65)\end{array}$ & $\begin{array}{c}1.53 \\
(0.46)\end{array}$ & $\begin{array}{c}1.09 \\
(0.57)\end{array}$ \\
\hline (3) $\mathrm{LR}(\mathrm{EXP} / \mathrm{GDP}) \mathrm{t}=\beta 0+\beta 1 \mathrm{LRGDPt}+\mu \mathrm{t}$ & $\begin{array}{l}\mathrm{C} \\
\text { LnGDP }\end{array}$ & $\begin{array}{c}-11.93 \\
1.05\end{array}$ & $\begin{array}{c}-4.00 \\
3.52\end{array}$ & $\begin{array}{c}1.00 \\
(0.60)\end{array}$ & $\begin{array}{c}3.17 \\
(0.36)\end{array}$ & $\begin{array}{c}0.82 \\
(0.66)\end{array}$ \\
\hline (4) $\mathrm{LR}(\mathrm{EXP} / \mathrm{GDP}) \mathrm{t}=\beta 0+\beta 1 \mathrm{LRPGDPt}+\mu \mathrm{t}$ & $\begin{array}{l}\mathrm{C} \\
\ln P G D \\
\mathrm{P}\end{array}$ & $\begin{array}{l}6.13 \\
1.41\end{array}$ & $\begin{array}{c}-3.01 \\
3.71\end{array}$ & $\begin{array}{c}1.05 \\
(0.58)\end{array}$ & $\begin{array}{c}3.44 \\
(0.32)\end{array}$ & $\begin{array}{c}1.06 \\
(0.58)\end{array}$ \\
\hline (5)LRPEXPt $=\beta 0+\beta 1 \mathrm{LRPGDPt}+\mu \mathrm{t}$ & $\begin{array}{l}\mathrm{C} \\
\ln P G D \\
\mathrm{P}\end{array}$ & $\begin{array}{c}-11.93 \\
2.43\end{array}$ & $\begin{array}{l}2.98 \\
6.23\end{array}$ & $\begin{array}{c}0.90 \\
(0.63)\end{array}$ & $\begin{array}{c}1.23 \\
(0.53)\end{array}$ & $\begin{array}{c}0.92 \\
(0.62)\end{array}$ \\
\hline
\end{tabular}


Optimum Ekonomi ve Yönetim Bilimleri Dergisi, Cilt 4, Sayı 1- http://dergipark.ulakbim.gov.tr/usakoeyb/

Abdiyeva ve Çetintaş -Kamu Harcamaları ve Ekonomik Büyüme Arasındaki İlişki: Kırgızistan Örneği

\begin{tabular}{clccccc}
\hline (6)LRGCt $=\beta 0+\beta 1 \mathrm{LRGDPt}+\mu \mathrm{t}$ & $\mathrm{C}$ & 3.85 & 0.71 & 1.05 & 1.85 & 1.25 \\
& & & & $(0.58)$ & $(0.39)$ & $(0.53)$ \\
\hline
\end{tabular}

$\chi_{\text {NOR }}^{2}$ Jarque-Bera normalite test istatistiğidir. $\chi_{\text {SER }}^{2}$ birinci dereceden ardışık bağımlılı̆̆ın Breusch-Godfrey (BG) test istatistiğidir. $\chi_{\text {LM }}^{2}$ Modelin artıklarının II mertebeden ardışık bağımlılık test istatistiğidir. Parantez içindeki değerler olasılık değerlerini göstermektedir.

Son aşamada tüm modeller için ARDL yöntemine dayalı uzun dönem ve hata düzeltme modeli tahmin edilmiştir. Yukarıda tahmin edilen koentegrasyon test sonuçları, değişkenler arasında uzun dönemli bir ilişkinin olabileceğini gösterdiğinden 6 modelin her biri için (9) nolu

$$
\ln Y=a_{0}+\sum_{i=1}^{k} a_{1 i} \ln Y_{t-i}+\sum_{i=0}^{l} a_{2 i} \ln X_{t-i}+\varepsilon_{t}
$$

ve (10) nolu hata düzeltme modelleri tahmin edilmiştir.

$$
\Delta \ln Y=a_{0}+\alpha_{1} E C T_{t-1}+\sum_{i=1}^{m} a_{2 i} \Delta \ln Y_{t-i}+\sum_{i=0}^{n} a_{3 i} \Delta \ln X_{t-i}+\varepsilon_{t}
$$

Tablo 5 ve tablo 6 sırasıyla uzun dönem ve hata düzeltme modeline ilişkin tahmin sonuçlarını göstermektedir ve bu modellerin tamamı \%5 önem düzeyinde tanımlayıcı testlerin tamamından geçmiştir. ECT değişkeni (9) nolu uzun dönem denge denkleminden elde edilen hata terimleri serisinin bir dönem gecikmeli değerini göstermektedir. ECT kısa dönemdeki dengesizliğin ne kadarının uzun dönemde düzeltileceğini göstermektedir. ECT katsayısının negatif ve istatistik bakımdan anlamlı olması beklenir.

Tablo 5 her bir modele için tahmin edilen uzun dönem katsayıları göstermektedir. 1.modelin uzun dönem katsayısı, milli gelirdeki yüzde 1'lik artışın uzun dönemde kamu harcamalarını yüzde 2.05 arttıracağını göstermektedir. 2.model milli gelirdeki yüzde 1'lik artışın uzun dönemde kamu harcamalarını yüzde $2.84 ; 3$. model $\% 1.05 ; 4$. model $\% 1.41 ; 5$.model $\% 2.43$ artıracağını göstermektedir 6. modelde ise uzun dönem katsayısı istatistiksel olarak anlamsızdır. Böylece, ilk beş modelin uzun dönem katsayılarına göre Kırgızistan'da reel GSYİH'daki yüzde 1'lik artış, kamu harcamalarında yüzde 1'den daha büyük oranda bir artışa neden olmaktadır.

Tablo 6. Modellerin Kısa Dönem Tahmini

\begin{tabular}{lclll}
\hline \multicolumn{1}{c}{ Model } & Değişken & Katsayı & T-degeri & Olasılık \\
\hline (1)LREXPt $=\beta 0+\beta 1 \mathrm{LRGDPt}+\mu \mathrm{t}$ & $\boldsymbol{E C} \boldsymbol{T}_{t-1}$ & -0.33 & -2.93 & 0.01 \\
& $\mathrm{~d}(\mathrm{LGDP})$ & & 3.54 & 0.00 \\
$(2) \mathrm{LREXPt}=\beta 0+\beta 1 \mathrm{LRPGDPt}+\mu \mathrm{t}$ & $\boldsymbol{E} \boldsymbol{C} \boldsymbol{T}_{t-1}$ & -0.32 & -2.93 & 0.01 \\
& $\mathrm{~d}(\mathrm{LPGDP})$ & & 3.54 & 0.00 \\
\hline$(3) \mathrm{LR}(\mathrm{EXP} / \mathrm{GDP}) \mathrm{t}=\beta 0+\beta 1 \mathrm{LRGDPt}+\mu \mathrm{t}$ & $\boldsymbol{E} \boldsymbol{C} \boldsymbol{T}_{t-1}$ & -0.32 & -1.47 & 0.01 \\
& $\mathrm{~d}(\mathrm{LGDP})$ & & -0.88 & 0.16 \\
\hline (4) $\mathrm{LR}(\mathrm{EXP} / \mathrm{GDP}) \mathrm{t}=\beta 0+\beta 1 \mathrm{LRPGDPt}+\mu \mathrm{t}$ & $\boldsymbol{E} \boldsymbol{C} \boldsymbol{T}_{t-1}$ & -0.34 & -3.08 & 0.01 \\
& $\mathrm{~d}(\operatorname{lnPGDP})$ & & -1.25 & 0.23 \\
\hline (5)LRPEXPt $=\beta 0+\beta 1 \mathrm{LRPGDPt}+\mu \mathrm{t}$ & $\boldsymbol{E C} \boldsymbol{T}_{t-1}$ & -0.33 & -3.02 & 0.01 \\
& $\mathrm{~d}(\operatorname{lnPGDP})$ & 3.67 & 0.00 & \\
\hline (6)LRGCt $=\beta 0+\beta 1 \mathrm{LRGDPt}+\mu \mathrm{t}$ & $\boldsymbol{E C} \boldsymbol{T}_{t-1}$ & -0.31 & -2.47 & 0.02 \\
& $\mathrm{~d}(\operatorname{lnGDP})$ & -0.57 & 0.57 & \\
\hline
\end{tabular}

Hata düzeltme modeline ilişkin tahmin sonuçları Tablo 6'da gösterilmektedir. Modelde hata düzeltme katsayısının tahmin edilen değeri $\left(E C T_{t-1}\right)-0.34$ ile -0.31 arasında değişmektedir. ECT 
katsayının işareti tüm modellerde beklendiği gibi negatiftir ve istatistiksel olarak \%5 önem düzeyinde anlamlıdır. Banerjee vd. (1998)'e göre hata düzeltme katsayısının istatistik açıdan anlamlılığı, değişkenler arasındaki koentegrasyonun daha üst düzey bir kanıtıdır. 6. Versiyona ilişkin hata düzeltme modelinde de ECT istatistik bakımdan anlamlıdır ve 6. model için daha önce karar veremediğimiz değişkenler arasındaki uzun dönemli ilişkinin varlığı, bu model ile doğrulanmaktadır.

Tablo 7: Nedensellik Tahmin Sonuçları

\begin{tabular}{|c|c|c|c|}
\hline & Model & ECT & NEDENSELLIKK \\
\hline \multirow[t]{2}{*}{ Model 1} & $\mathrm{LREXPt}=\beta_{0}+\beta_{1} \mathrm{LRGDPt}+\mu \mathrm{t}$ & $-2.93 * * *$ & $\mathrm{GDP} \longrightarrow \mathrm{EXP}$ \\
\hline & $\mathrm{LRGDPt}=\beta_{0}+\beta_{1} \mathrm{LREXPt}+\mu \mathrm{t}$ & -0.53 & $\mathrm{EXP} \nrightarrow \mathrm{GDP}$ \\
\hline \multirow[t]{2}{*}{ Model 2} & $\mathrm{LREXPt}=\beta_{0}+\beta_{1} \mathrm{LRPGDPt}+\mu \mathrm{t}$ & $-2,92 * * *$ & $\mathrm{PGDP} \rightarrow \mathrm{EXP}$ \\
\hline & $\mathrm{LRPGDPt}=\beta_{0}+\beta_{1} \mathrm{LREXPt}+\mu \mathrm{t}$ & -1.64 & $\mathrm{EXP} \nrightarrow \mathrm{PGDP}$ \\
\hline \multirow[t]{3}{*}{ Model 3} & $\mathrm{LR}(\mathrm{EXP} / \mathrm{GDP}) \mathrm{t}=\beta_{0}+\beta_{1} \mathrm{LRGDPt}+\mu \mathrm{t}$ & -1.47 & $\mathrm{GDP} \longrightarrow \mathrm{EXP} / \mathrm{GDP}$ \\
\hline & LRGDP $\mathrm{t}=\beta_{0}+\beta_{1} \mathrm{LR}(\mathrm{EXP} / \mathrm{GDP}) \mathrm{t}+\mu \mathrm{t}$ & $* * *$ & \\
\hline & & -0.03 & $\mathrm{EXP} / \mathrm{GDP} / \mathrm{GDP}$ \\
\hline \multirow[t]{2}{*}{ Model 4} & $\mathrm{LR}(\mathrm{EXP} / \mathrm{GDP}) \mathrm{t}=\beta_{0}+\beta_{1} \mathrm{LRPGDPt}+\mu \mathrm{t}$ & $-3.08 * * *$ & $\mathrm{PGDP} \longrightarrow \mathrm{EXP} / \mathrm{GDP}$ \\
\hline & $\mathrm{LRPGDPt}=\beta_{0}+\beta_{1} \mathrm{LR}(\mathrm{EXP} / \mathrm{GDP}) \mathrm{t}+\mu \mathrm{t}$ & 1.35 & $\mathrm{EXP} / \mathrm{GDP} / \mathrm{PGDP}$ \\
\hline \multirow[t]{2}{*}{ Model 5} & $\mathrm{LRPEXPt}=\beta_{0}+\beta_{1} \mathrm{LRPGDPt}+\mu \mathrm{t}$ & $-3.02 * * *$ & $\mathrm{PGDP} \rightarrow \mathrm{PEXP}$ \\
\hline & LRLRPGDPt $=\beta_{0}+\beta_{1} \mathrm{PEXPt}+\mu \mathrm{t}$ & -1.49 & $\mathrm{PEXP} \nrightarrow \mathrm{PGDP}$ \\
\hline \multirow[t]{2}{*}{ Model 6} & $\mathrm{LRGCt}=\beta_{0}+\beta_{1} \mathrm{LRGDPt}+\mu \mathrm{t}$ & $-2.47 * *$ & $\mathrm{GDP} \longrightarrow \mathrm{GC}$ \\
\hline & $\mathrm{LRGDPt}=\beta_{0}+\beta_{1} \mathrm{LRGCt}+\mu \mathrm{t}$ & -0.36 & $\mathrm{GC} \nrightarrow \mathrm{GDP}$ \\
\hline
\end{tabular}

** ve *** sirasıyla \%5 ve \%1 önem düzeylerini göstermektedir

Son olarak yine ARDL yöntemi kullanarak kamu harcamaları ve ekonomik büyüme arasındaki uzun dönem nedensellik (10) nolu hata düzeltme modeli kullanılarak tahmin edilebilir. Nedensellik tahmin sonuçları tablo 7'de verilmiştir. Kamu harcamalarına ilişkin göstergenin bağımlı değişken olarak alındığı üstteki 6 model için tahmin edilen hata düzeltme modellerinde ECT'nin katsayıs1 \%5 önem düzeyinde istatistik bakımdan anlamlıdır ve uzun dönem nedenselliği göstermektedir. Dolayısıyla ekonomik büyümenin kamu harcamalarının Granger nedeni olmadığı şeklindeki sıfır hipotezi üstteki modellerin hepsinde reddedilmektedir. Aksine (10) nolu hata düzeltme modeli üstteki her bir model için yeniden ekonomik büyüme bağımlı değişken olarak alınıp tahmin edildiğinde, tüm modellerde ECT katsaysı istatistik bakımdan anlamsız bulunmakta ve kamu harcamalarının ekonomik büyümenin Granger nedeni olmadığı şeklindeki sıfır hipotezi reddedilememektedir.

Sonuç olarak nedensellik test sonuçları uzun dönemde kamu harcamaları ve ekonomik büyüme arasında ekonomik büyümeden kamu harcamalarına doğru işleyen, tek yönlü uzun dönem bir nedenselliğin bulunduğunu göstermektedir. Ekonomik büyümeden kamu harcamalarına tek yönlü bu nedensellik bulgusu, analiz edilen dönem içerisinde Kırgızistan için Keynesyen hipotezi reddeder iken, Wagner hipotezinin geçerli olduğunu doğrulamaktadır.

Tahmin edilen uzun dönem modellerin yapısal kararlığını sınamak için ayrıca CUSUM ve CUSUMSQ kararlılık testleri yapılmıştır. Grafiklerden elde edilen kanıtlar, tahmin edilen tüm modellerin analiz edilen dönem sürecince kararlı olduğunu göstermektedir. 
Tablo 8: Modellerin CUSUM Test Sonuçları

1. Modelin CUSUM ve CUSUMSQ Test Sonuçları
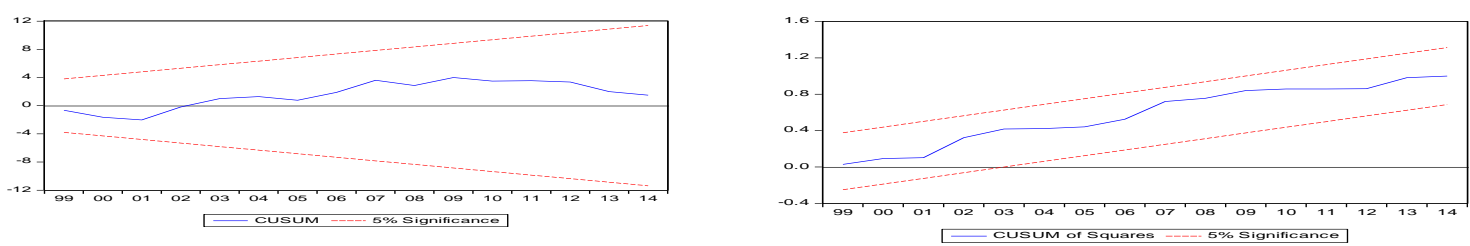

2. Modelin CUSUM ve CUSUMSQ Test Sonuçları
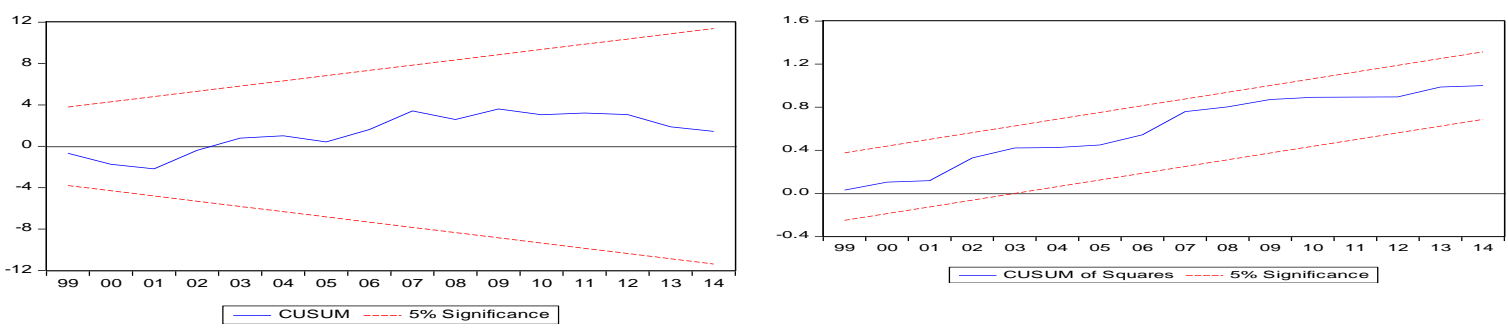

3. Modelin CUSUM ve CUSUMSQ Test Sonuçları
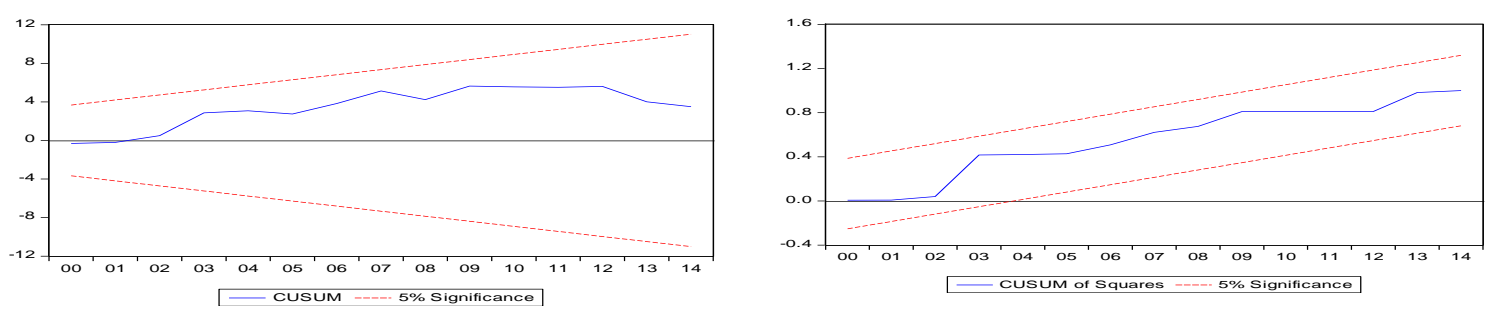

4. Modelin CUSUM ve CUSUMSQ Test Sonuçları
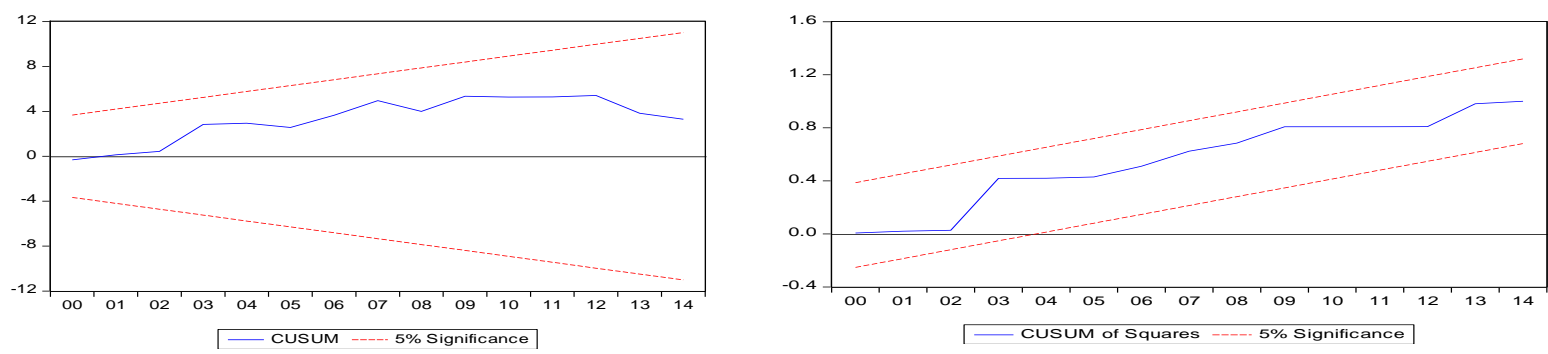

5. Modelin CUSUM ve CUSUMSQ Test Sonuçları
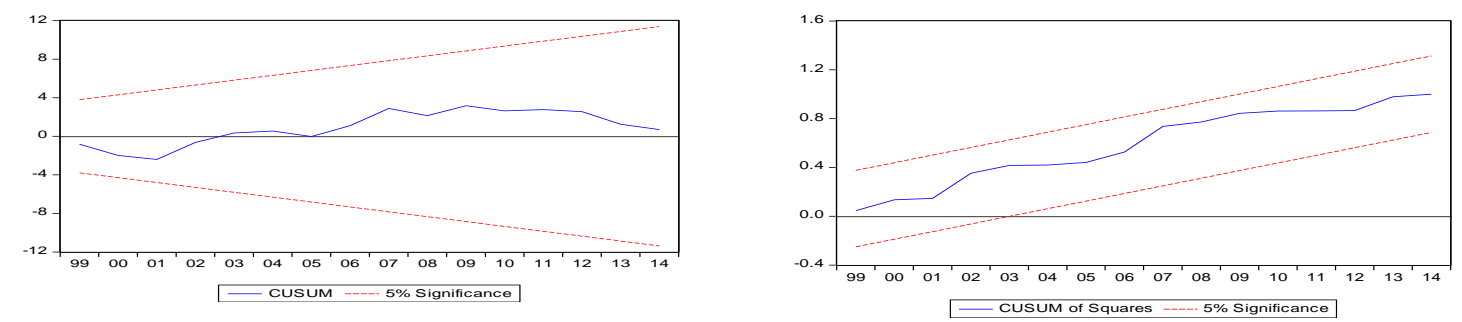


\section{Modelin CUSUM ve CUSUMSQ Test Sonuçları}
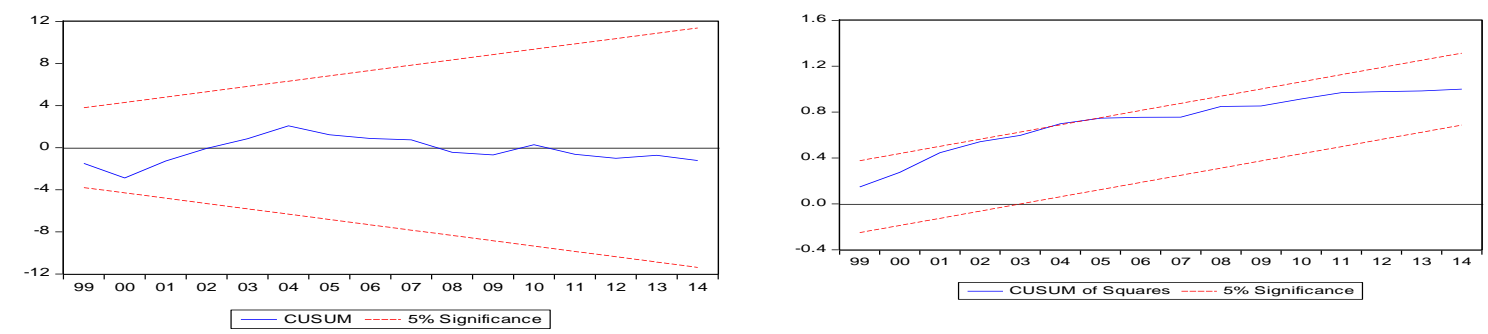

\section{SONUÇ VE DEĞERLENDİRME}

Bu çalışmada 1995-2014 döneminde Kırgızistan'da kamu harcamaları ile ekonomik büyüme arasındaki ilişkiler araştırılmış ve Wagner kanununun geçerli olup olmadığı test edilmiştir. Kırgızistan 1991 yılında bağımsızlığını kazandığı için sınırlı bir veri seti ile çalışılmıştır. Bu nedenle çalışmada ulaşılan sonuçlarda bu husus gözden kaçırılmamalıdır. Birim kök testleri serilerin farklarının durağan olduğunu göstermektedir. Kamu harcamaları ve ekonomik büyüme arasındaki uzun dönem ve nedensellik ilişkilerini araştırmak ve Wagner kanununun geçerliliğini test etmek için Wagner kanununun literatürde yaygın olarak kullanılan 6 farklı modelinden yararlanılmıştır. Tahmin edilen tüm modeller iki değişken arasında uzun dönemde bir ilişkinin bulunduğunu göstermektedir. Kamu harcamalarının gelir esnekliği tüm modellerde birden büyüktür ve esnektir. Diğer bir ifadeyle, genel olarak GSYIH \% 1 oranında arttığında uzun dönemde kamu harcamaları \% 1'den daha yüksek bir oranda artmaktadir.

Nedensellik test sonuçları ise kamu harcamaları ve ekonomik büyüme arasında, ekonomik büyümeden kamu harcamalarına tek yönlü bir nedenselliğin olduğunu göstermektedir. Bu tek yönlü nedensellik bulgusu analiz edilen dönem içerisinde kamu harcamalarının ekonomik büyümeyi arttıracağını ifade eden Keynesyen hipotezi reddeder iken, milli gelirdeki artışın kamu harcamalarını artıracağını ifade eden Wagner kanununu desteklemektedir. Gerçekten Kırgızistan'da son yıllarda hızlı bir kentleşme gerçekleşmiştir. Kalite düzeyinde bir değişme olmamakla birlikte, kamu hizmetlerinin özellikle altyapı ve sosyal hizmetlerin sayısında önemli artışlar olmuştur.

Genel olarak Wagner kanununun daha çok gelişmiş ve geçiş ekonomilerinde geçerli olduğu soylenebilir. Fakat bu ülkelerde kamu harcamalarının milli gelirden daha hızlı bir şekilde artmasının nedenleri ve dayandığı kaynaklar biribirinden farklıdır. Gelişmiş ülkelerde kamu harcamaları reel gelirin yükselerek ve daha çok, daha kaliteli kamu hizmetlerine olan talebin yükselmesi ve vergilere dayalı olarak artmaktadır. Geçiş ekonomilerinde ise ekonomik, sosyal ve yapısal reformlar ve özellikle altyapı harcamalarından dolayı daha çok dış borçlarla finanse edilen kamu harcamaları hızlı bir şekilde artmaktadır. Gelişmekte olan ülkeler ne vergilerini ne de borçlarını fazla arttıramadıklarından dolayı Wagner hipotezinin çoğu zaman bu ülkeler için geçerli olmadığı ileri sürülmektedir. 


\section{KAYNAKÇA}

Abizadeh, S. \& Gray, J. (1985). Wagner's Law: a Pooled Time-Series Cross-Section Comparison, National Tax Journal, 88, 209-18.

Antonis A., K. Constantinos \& Persefoni T. (2013). Wagner's Law versus Keynesian Hypothesis: Evidence from pre WWII Greece. Panoeconomicus, 4, 457-472.

Bagdigen M. \& H. Çetintaş. (2004). Causality between Public Expenditure and Economic Growth: The Turkish Case. Journal of Economics and Social Research, Vol. 6, No. 1, 53-72.

Banerjee, A., Dolado, J. \& Mestre, R., (1998). Error-correction mechanism tests for cointegration in a single-equation framework. Journal of Time Series Analysis, 19, 267-283.

Bayrak, M. \& Esen, Ö. (2014). Examining the Validity of Wagner's Law in the OECD Economies, Research in Applied Economics, Volume 6, No 4, http://www.macrothink.org/journal/index.php/rae/article/view/5354/5017

Bayrak, M. ve Esen Ö. (2015). Kamu Harcamaları ve Ekonomik Buyume İlişkisi: Geciş Surecindeki Turk Cumhuriyetleri Uzerine Bir Uygulama, Bilig, Bahar, Sayı 73, 231-248

Bojanic A.N. (2013). Testing the Validity of Wagner's Law in Bolivia: A Cointegration and Causality Analysis with Disaggregated Data, Revista de Análisis Económico, Vol. 28, No.1, 25-45

Granger, C. W. J., \& Newbold, P. (1974). Spurious Regressions in Econometrics. Journal of Econometrics 2, 111-120.

Henrekson, M. (1993). Wagner's Law a spurious relationship, Public Finance, 48, 406-415.

IMF, 2002. IMF Country Report No: 02/150

IMF, 2016. IMF County Report No 16/56

Jaen-Garcia, M. (2011). Empirical Analysis of Wagner's Law for the Spain's Regions, International Journal of Academic Research in Accounting, Finance and Management Sciences. 1(1): 1-17.

Kırgız Cumhuriyeti Milli İstatistik Komitesi, www.stat.kg

Kuckuck, J. (2012). Testing Wagners's Law at Different Stages of Economic Development A Historical Analysis of Five Western European Countries. Istitute of Empirical Economic Research, Working Paper 91, Germany.

Mahdavi, S. (2009). A Re-examination of Wagner's Law Based on Disaggregated U.S. State-Local Government Expenditure. Working Paper 0101ECO-090-2009, The University of Texas at San Antonio, College of Business.

Narayan, P. K. (2005). The saving and Investment Nexus for China: Evidence from Cointegration Tests. Applied Economics. 37, 1979-1990.

Oktayer, A. \& N. Oktayer. (2013). Testing Wagner's Law For Turkey: Evidence From A Trivariate Causality Analysis, Prague Economic Papers, S.2, p.284-301

Permana Y.H \& Vika, G.S.J. J. (2014). Testing the Existence of Wagner Law and Government Expenditure Volatility in Indonesia Post-Reformation Era, Journal of Economics and Sustainable Development, 5(2), 130-139.

Pesaran, M. H., Shin, Y. \& Smith, R. J. (2001). Bounds testing approaches to the analysis of level relationships. Journal of Applied Econometrics, 16, 289-326.

Peters A. C. (1996). An Application of Wagner's “Law” of Expanding State Activity to Totally Diverse Countries. ECCB Staff Research Paper, Eastern Caribbean Central Bank.

Ram, R. (1986). Causality Between Income and Government Expenditure: A Broad International Perspective. Public Finance, 41, 393-413.

Richter, Ch. \& Dimitrios, P. (2012) The Validity of Wagner's Law in the United Kingdom for the Period 1850-2010. Working Paper. International Network for Economic Research, Bonn, Germany.

Sentr sotsialno-ekonomiçeskih issledovaniy (Центр социально-экономических исследований в Кыргызстане). (2011). Анализ государственных расходов на социальный сектор в Кыргызской Республике, ЮНИСЕФ, Бишкек.

Sideris, D. (2007). Wagner's Law in 19th century Greece: a cointegration and causality analysis. Bank of Greece working paper No. 64, Bank of Greece.

Thornton, J. (1999). Cointegration, Causality and Wagner's Law in $19^{\text {th }}$ Century Europe. Applied Economics Letters, 6(7): 413-16. 
Optimum Journal of Economics and Management Sciences, Vo1. 4, No. 1- http://dergipark.ulakbim.gov.tr/usakoeyb/

Abdiyeva and Çetintaş_Cointegration and Causality Between Public Expenditutre and Economic Growth: Case of

Kyrgyzstan

Verma, S. \& Arora, R. (2010). Does the Indian Economy Support Wagner's Law? An Econometric Analysis, Eurasian Journal of Business and Economics, 3 (5), 77-91.

World Bank. (2014). Kyrgyz Republic - Public expenditure review policy notes: strategic setting. Public Expenditure Review (PER). Washington, D.C.: World Bank Group. http://documents.worldbank.org/curated/en/2015/06/24607685/kyrgyzrepublic-public-expenditure-review-policy-notes-strategic-setting

Yamak, N. ve Küçükkale, Y. (1997). Türkiye’de Kamu Harcamaları Ekonomik Büyüme İlişkisi. İktisat, İşletme ve Finans, 12(131), 5-14.

Zheng, Y., Li,J., Wang, X. \& Li Ch. (2010). An Empirical Analysis of the Validity of Wagner's Law in China A Case Study Based on Gibbs Sampler. International Journal of Business and Management, Vol. 5, No. 6, 161-168.

Zivot, E. \& Andrews D. W.K., (1992). Further Evidence on the Great Crash, the Oil Price Shock, and the Unit Root Hypothesis. Journal of Business and Economic Statistics, 10, 251-270.

https://www.quandl.com/data/WORLDBANK/KGZ NYGDPMKTPXN-Kyrgyz-Republic-GDP-deflator-LCU, 01.05.2016 